ACTA THERIOLOGICA

Vol. 27, 22: 295-304, 1982

\title{
The Influence of Temperature on the Activity and Food Consumption of the Common Shrew
}

\author{
Sara CHURCHFIELD ${ }^{1}$
}

\begin{abstract}
Churchfield S., 1982: The influence of temperature on the activity and food consumption of the common shrew. Acta theriol., 27, 22: 295-304 [With 2 Tables \& 1 Fig.]

The activity of Sorex araneus Linnaeus, 1758 was investigated using time-lapse photography and food consumption was monitored in metabolic cages under winter and summer conditions of temperature and daylength. Shrews were active throughout the 24-hour period at summer temperatures but were more active during darkness than during the light under both summer and winter conditions. Activity was greater in summer than in winter. Shrews were active outside the nest for $28 \%$ of the 24 -hour period in summer but only $19 \%$ in winter, and activity periods were reduced from a mean of 6 minutes in summer to 3 minutes in winter. Rest periods in the nest tended to be longer at winter temperatures (maximum $5^{1 / 4}$ hours) than at summer temperatures (maximum 11/2 hours). Assimilation efficiency of shrews was not affected by ambient temperature but food consumption was reduced under winter conditions. It is suggested that a reduction in activity may be a means of minimising energy expenditure and predation in winter, and may be a tactic to assist the overwintering of shrews.
\end{abstract}

[Dept. Zoology, Westfield College, Univ, London, Kidderpore Avenue, London, NW3 7ST, England]

\section{INTRODUCTION}

Trapping studies and the use of mark-recapture techniques suggest that Sorex araneus has smaller home-ranges and reduced activity on the ground surface in winter compared with summer (Shillito, 1963; Churchfield, 1980). This is reflected in lower numbers of captures in winter than in summer, even though overwintering survival is high (Crowcroft, 1954a ; Mezhzherin, 1960 ; Pernetta, 1977 ; Churchfield, 1980). A reduction in the amount of activity on the ground surface in cold conditions could be a useful overwintering strategy to minimise energy expenditure but little information is available on the seasonal behaviour of wild shrews.

The activity patterns of captive shrews of different ages and in different seasons have, however, been described in detail in laboratory

1 Dept. Biol. Sci., Chelsea College, Univ. London, Hortensia Road, London, SW10 OQR, England.

9 - Acta Theriologica

[295] 
studies but these have mostly been carried out under conditions of relative warmth compared with ambient temperatures outdoors, and often with a constant regime of light and dark periods (Tupikova, 1949 ; Crowcroft, 1954b ; Gebczynski, 1965; and Loxton et al., 1975). Buchalczyk (1972) investigated seasonal activity of captive shrews outdoors and found that locomotor and feeding activity were reduced in winter, but did not provide temperature recordings. Moreover, locomotor activity was determined by the number of times a shrew vacated its nest-box and she took no account of the length of the activity or rest periods. Feeding activity was estimated by the number of visits made by a shrew to a feeding box but the amount of food consumed, or even whether food was eaten at all, was not determined. Consequently, little is known of the effects of temperature on the activity patterns of shrews, the time they spend in the nest or their energy requirements.

This paper presents an investigation into the activity and food consumption of captive $S$, araneus under winter and summer conditions of temperature and daylength.

\section{METHODS}

The activity of $S$. araneus was investigated using time-lapse photography. Shrews were maintained individually in lid-less plastic bins measuring $500 \mathrm{~mm}$ by $370 \mathrm{~mm}$. Sawdust was placed in each bin, together with a small amount of hay sufficient to provide some cover without hiding the shrew from view. A perspex nest-box containing hay bedding was provided at one end of the bin. Food (Calliphora pupae) and water were placed in separate jars at the opposite end of the bin. Shrews were maintained under these conditions for up to 18 months in succession and so were quite accustomed to them.

Filming was carried out using a Vinten Mark 3, $16 \mathrm{~mm}$ Scientific Time-Lapse Camera set to give a time-lapse interval of 15 seconds between exposures, and coupled to a short duration electronic flash. The interval between exposures was just sufficient to enable a shrew to vacate its nest-box and run back into it without appearing on the film but previous trial observations showed that both activity and rest periods of shrews extended over several minutes and even hours at a time and sojourns from the nest were very rarely of less than 15 seconds duration.

The camera was set up above the shrew's bin so that the whole enclosure was in the field of view. Shrews showed no reaction to the flashes, continuing to feed and explore for considerable periods in the open without any apparent disturbance.

Three shrews were each filmed for two consecutive 24-hour periods under summer and winter conditions of temperature and daylength. Activity was investigated in the laboratory in May at a constant temperature of $20^{\circ} \mathrm{C}$ when similar ambient temperatures were recorded outdoors. Activity was also recorded in an outdoor shed (allowing protection from rain) in February where the daily ambient temperature ranged from $1^{\circ} \mathrm{C}$ at night to $9^{\circ} \mathrm{C}$ during the day. It was the purpose of this study to investigate changes in activity of shrews resulting from gross 
seasonal temperature differences and no allowance was made for the possible effects of a constant daily temperature regime in summer and a slightly fluctuating temperature regime in winter on the eircadian rhythms of shrews. Natural lighting was used, which in the laboratory was augmented by fluorescent tubes and outdoors was provided via windows in the shed. All the shrews used were of the same age class (young adults).

Following processing, each film was projected on to a screen using a specto $16 \mathrm{~mm}$ Motion Analysis Projector, and all frames in which a shrew appeared were recorded. The time spent active outside the nest in each successive 30 minutes throughout the 24-hour period was summed, the duration of activity periods outside the nest and of rest periods spent inside the nest were calculated on the basis that the interval between successive frames was 15 seconds.

Food consumption and faecal ejection of shrews were monitored similarly under winter and summer conditions using metabolic cages, each measuring $965 \mathrm{~mm}$ by $300 \mathrm{~mm}$. Each cage housed a single shrew and comprised a perspex chamber with a floor of stainless steel mesh with $5 \mathrm{~mm}$ diameter holes through which faecal material could fall into a collection tray below. A nest-box with cotton wool bedding was provided. Food (Calliphora pupae) and water were provided daily in steep-sided jars to prevent escape and spillage. Control jars of food, which were not given to the shrews, were weighed daily to take account of any weight changes in the pupae.

The shrews were habituated to the apparatus for 24 hours before monitoring commenced. Measurements of food consumption and faecal production were made at 24-hourly intervals for $3-4$ consecutive days and means calculated. The metabolic cage plus the nest and food and water jars were searched for food remains and faecal material, but shrews rarely defaecated in their water. The collection of faeces and urine separately provided impracticable and so both fractions were collected together and classed as rejecta. Faecal material was dried at $60^{\circ} \mathrm{C}$ to constant weight and food consumed was converted to dry weight for estimates of assimilation efficiency which was calculated according to the formula:

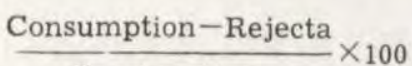

Consumption

\section{RESULTS}

The combined results for all the shrews filmed can be seen in Figure 1 where the mean time spent active in each successive 30 minutes during the 24-hour period is shown. Shrews were active throughout the day and night except during the winter temperature regime when activity was greatly reduced between 0730 hours and 0930 hours. Individuals showed peaks of activity every $1-2$ hours with occasional rest periods spent in the nest of longer duration (maximum $5^{1 / 4}$ hours).

The cycles of activity of individuals filmed on separate occasions and of different individuals were similar but peaks of activity were often displaced by approximately 1 hour. The levels of activity were also similar although sometimes a shrew was more active on one occasion 
than on another or was more active than its fellows, even though conditions were the same.

Shrews were significantly more active during hours of darkness than in the light in both temperature regimes. This is demonstrated in Table 1 where mean activity time per 30-minute period and mean lengths of activity periods are given, together with the results of "Student's" $t$-tests.

The major difference between the activity of shrews under the winter and summer regimes was not so much the cycle of activity as the level

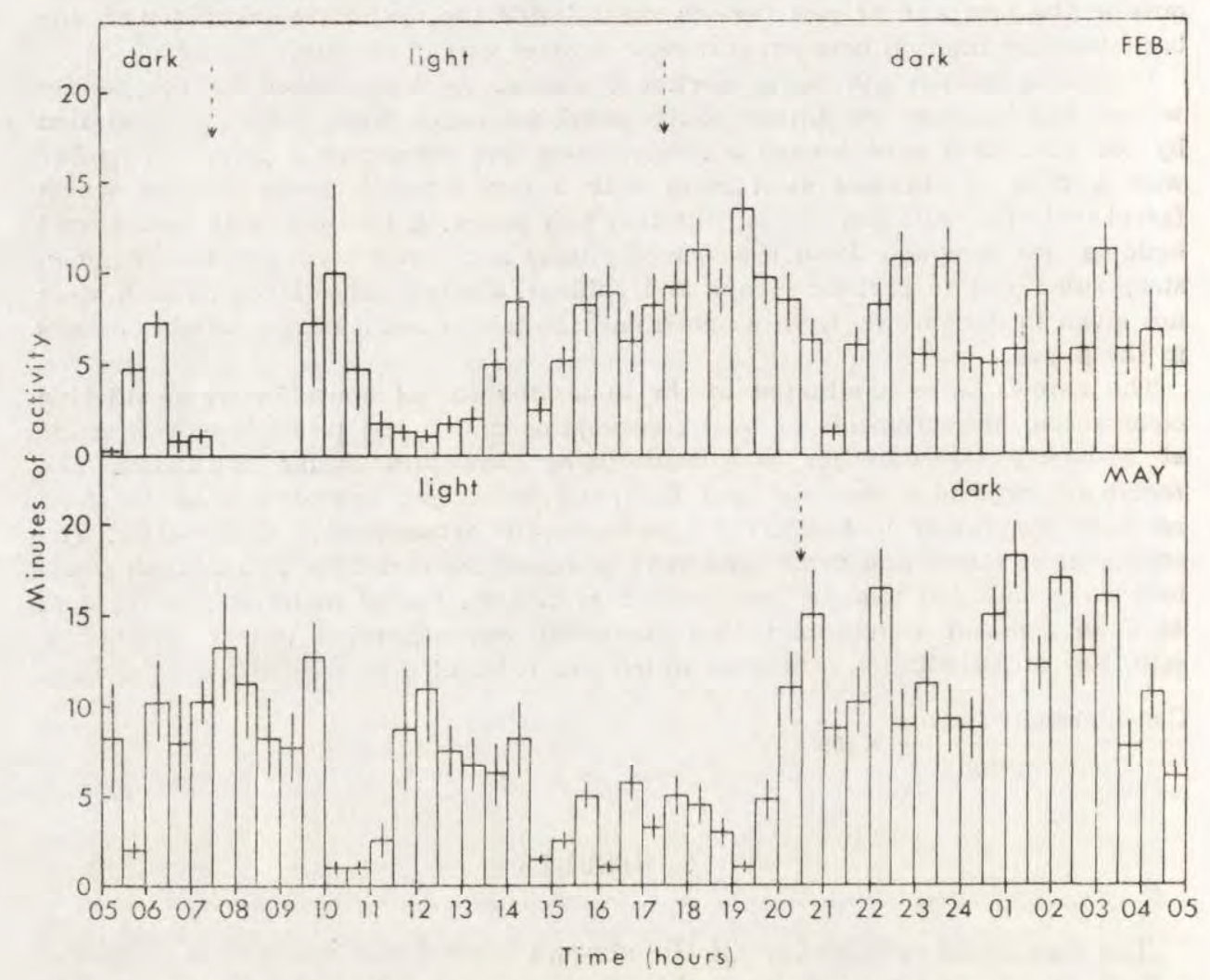

Fig. 1. Activity of captive $S$. araneus throughout the 24-hour period in summer and winter, with standard errors.

of activity. Shrews were more active at summer temperatures than at winter temperatures in terms of mean activity per 30 minutes (mean 8 mins. and 6 mins. respectively, $t=3.17, P<0.01$ ). When the lengths of activity periods were examined it was found that shrews spent longer periods outside the nest at summer temperatures than at winter temperatures (mean 6 mins. and 3 mins. respectively, $t=5.90, P<0.001$ ).

The level of activity in the light and dark periods varied with the 
temperature. Table 1 indicates that activity in successive 30 -minute periods was similar during the light at both temperature regimes but the lengths of activity periods were greater in summer than in winter $(t=3.65, P<0.001)$. During hours of darkness, activity per 30 -minute period and the lengths of activity periods were greater in summer than in winter ( $t=4.81, P<0.001 ; t=5.17, P<0.001$, respectively).

When not engaged in some activity outside the nest, such as foraging, grooming and exploring, shrews remained relatively inactive in their nests. Rest periods lasted for a mean of 13 minutes in both temperature

Table 1

Activity of captive $S$. araneus under summer and winter conditions of temperature and day length, with results of 'Student's' $t$-tests $\left(* P<0.001,{ }^{* *} P<0.05\right)$

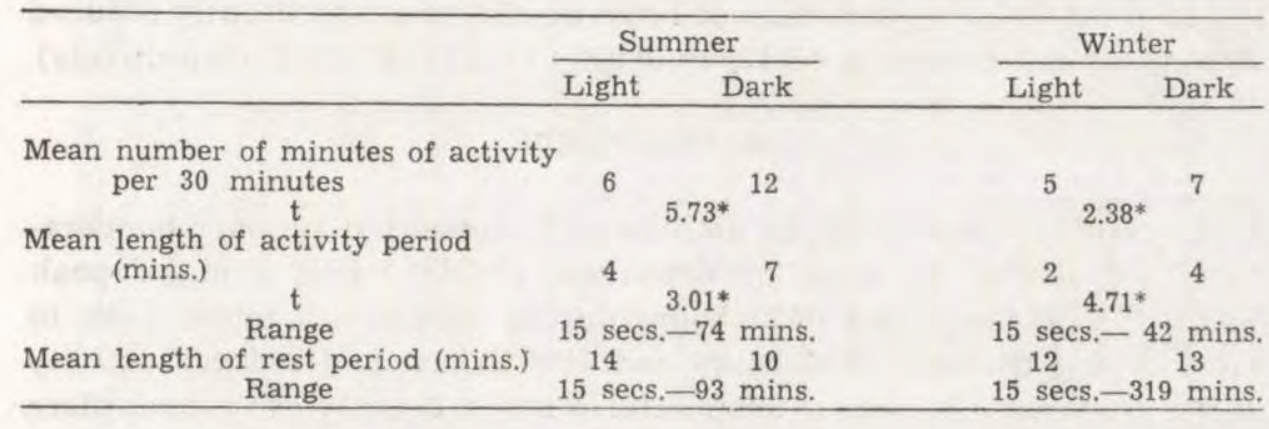

Table 2

Daily food consumption and assimilation efficiency of captive $S$. araneus under summer and winter conditions of temperature and daylength (with SD).

\begin{tabular}{|c|c|c|}
\hline & Summer & Winter \\
\hline $\begin{array}{l}\text { Sample size } \\
\text { Mean body weight (g) } \\
\text { Mean food intake (wet weight g) } \\
\text { Mean food intake as } \% \text { of body } \\
\text { weight (wet weight) }\end{array}$ & $\begin{array}{ll}15 & \\
8.10 & \\
8.26 & (1.94) \\
97.14 & (22.42)\end{array}$ & $\begin{array}{ll}20 & \\
8.17 & \\
6.38 & (1.34) \\
79.20 & (16.87)\end{array}$ \\
\hline Mean assimilation efficiency $(\%)$ & $85.51 \quad(3.61)$ & $84.36 \quad(5.79)$ \\
\hline
\end{tabular}

regimes but were often considerably longer : the maximum rest period recorded under summer conditions was $1^{1 / 2}$ hours and under winter conditions it was $5^{1 / 4}$ hours. S. araneus needs to feed regularly every few hours but some shrews have a tendency to hoard food, usually in their nests. Hoarding was observed in one shrew in the present study which could then feed without venturing from the nest-box, and as a result had longer rest periods than the non-hoarding shrews.

To summarise, the activity of $S$. araneus consisted of a system of short bursts of activity alternating with rest periods spent in the nest 
Activity was greater during darkness than in the light. Total activity was reduced in cold conditions: at summer temperatures shrews spent an average of $27.6 \%$ of their time in the 24-hour period engaged in activity outside the nest, whereas at winter temperatures activity fell to $18.8 \%$.

A comparison of food consumption by shrews in plastic bins measuring $550 \mathrm{~mm}$ by $307 \mathrm{~mm}$ (the usual conditions of captivity) and in metabolic cages revealed no significant difference between the results. The results of monitoring food consumption and assimilation efficiency in metabolic cages, together with sample sizes are shown in Table 2 . There was no difference in assimilation efficiency between the two temperature regimes but food consumption, both in terms of absolute food intake and food intake as a percentage of body weight, was significantly reduced at winter temperatures ( $t=3.42, P<0.002 ; t=2.71, P<0.02$, respectively).

\section{DISCUSSION}

The results obtained for the activity of $S$. araneus at summer temperatures are similar to those of Crowcroft (1954b), with a major peak between 2030 hours and 0430 hours during darkness, a minor peak in the morning between 0600 hours and 1000 hours, and reduced activity in the afternoon. At winter temperatures major activity again took place at night and diminished towards daylight, with another peak between 0930 hours and 1030 hours followed by reduced activity before a progressive increase prior to dusk. Activity was greatest during darkness, which was also observed by Crowcroft (1954b), Jansky \& Hanak (1960), Loxton et al. (1975) and Pankakoski (1979).

The reduced levels of activity at low temperatures support the findings of Jansky \& Hanak (1960) whose captures of wild shrews revealed changes in daily activity between April and November, and Buchalczyk (1972) who found that activity of captive shrews in terms of the number of exits from the nest-box, was greatest in summer but declined in autumn and winter. Loxton et al. (1975) showed that the diurnal cycle of activity of captive $S$. araneus was similar in winter at $13-20^{\circ} \mathrm{C}$ and in summer at $18-23^{\circ} \mathrm{C}$ but the overall activity was lower in winter, even at higher temperatures than those of the present study. These results suggest that shrews have particular seasonal levels of activity which are influenced by changes in ambient temperature. Results indicate that the alternation of dark and light periods have an important effect on the levels of activity of shrews but little is known about the effects of temperature changes over the 24-hour period on the daily cycle of activity and this would be worthy of further study. 
In addition to temperature, the length of the photoperiod may have contributed to the differences in activity recorded at the two temperature regimes. Shrews were notably more active during darkness than in the light and the shorter dark period in summer could have encouraged the higher levels of activity to compensate for the reduced dark period. However, total activity was reduced in winter despite the longer dark period which tends to refute this.

The age of the shrews, and particularly their reproductive condition, also seems to have an important influence on activity (Buchalczyk, 1972). Wild shrews overwinter in immature condition but become reproductively mature from March onwards. This is accompanied by an increase in their activity on the ground surface as they search for mates. The captive shrews were probably similarly influenced in May, by which time they were all sexually mature, while in February they were still immature.

The reduced level of activity with a tendency to spend longer periods in the nest at low temperatures probably contributed to the decrease in food consumption observed in the present study, not only as a result of moderating energy expenditure through a reduction in locomotor activity but also by reducing heat loss. Both absolute food consumption and food consumption as a percentage of body weight were reduced at low temperatures which seem to contradict the findings of Wolk (1969) who found an increase in food intake as a percentage of body weight in winter. However, Wołk's results may be attributed to changes in body weight of shrews rather than to differences in ambient temperature. Her captive shrews maintained outdoors underwent marked seasonal changes in body weight which paralleled the weight changes exhibited by wild shrews. They underwent a decrease in weight in winter, and an increase to maturity in spring and summer, with a mean difference of approximately $2 \mathrm{~g}$. Thus, the increase in food consumption as a $\%$ of body weight would be expected in winter when shrews had lower body weights. This phenomenon was not encountered in the present study because shrews were normally maintained at a constant temperature of $20^{\circ} \mathrm{C}$ and did not show such marked seasonal changes: there was no significant difference in body weight between the two temperature regimes. The body weight of shrews remained relatively stable during the experiments : at $20^{\circ} \mathrm{C}$ little change occurred and $1-9^{\circ} \mathrm{C}$ there was a mean weight change of $-0.48 \mathrm{~g}$.

Similarly, a decrease in body weight in winter might be expected to be accompanied by a fall in absolute food intake. Wołk (1969) states that absolute food intake was slightly higher in winter compared with summer but closer examination of her results shows that food intake 
of young adults actually decreased from summer to winter, reaching a minimum in November, and then increased to a maximum in March, when shrews are becoming reproductively active.

The assimilation efficiency of shrews did not differ between summer and winter conditions, indicating that changes in ambient temperature did not affect the digestion of food.

Captive shrews had a plentiful and easily accessible food supply which reduced the need for extensive foraging activity. The activity of wild shrews is probably considerably greater owing to the dispersed nature of the food supply, although even in winter food seems to be abundant (Churchfield, 1982). The difference in activity recorded between the two temperature regimes was not great (for example, total activity over the 24 -hour period in summer was $6^{1 / 2}$ hours compared with $4^{1 / 2}$ hours in winter) but despite this and the possible underestimation of activity obtained from laboratory studies, the results have provided an indication of the effects of temperature and photoperiod on activity which has important implications. By spending long periods in the nest and venturing out for short foraging excursions, and by adopting a more subterranean habit in winter where conditions are warmer than on the ground surface, heat loss could be greatly reduced. This would be further assisted by food caching, which is quite common in captive shrews. Reduced activity outside the nest could result in an overall reduction in energy requirements which in turn would allow a fall in food intake, such as was seen in the present study, and a decreased need to forage. $S$. sinuosus has been observed to enter a reversible torpor-like state with a reduced metabolic rate (Newman \& Rudd, 1978) but the extent of torpor in shrews and the conditions for its inducement are unknown. Finally, reduced activity on the ground surface would also lessen the chances of predation at a time when vegetative cover is sparse. Seasonal changes in activity could, therefore, be of considerable importance to the overwintering success of shrews, and could provide an explanation for reduced numbers of captures in winter.

Acknowledgements: I wish to thank Dr. J. Gurnell for providing help and useful discussion in the preparation of this manuscript. My appreciation also goes to Dr. J. Griffith, Prof. J.E. Webb and the members of Westfield College for providing help and facilities. This research was carried out during tenure of a postgraduate studentship (Mary Scharlieb Award) administered by the University of London, to whom I extend my thanks.

\section{REFERENCES}

1. Buchalczyk A., 1972: Seasonal variations in the activity of shrews. Acta theriol., 17: $221-243$, 
2. Churchfield S., 1980: Population dynamics and the seasonal fluctuations in numbers of the common shrew in Britain. Acta theriol., 25: 415-424.

2. Churchfield S., 1982: Food availability and the diet of the common shrew, Sorex araneus, in Britain. J. Anim. Ecol., 51: 15-28.

4. Croweroft W. P., 1954a: An ecological study of British shrews. D. Phil. unpubl. thesis, University of Oxford.

5. Crowcroft W. P., 1954b: The daily cycle of activity in British shrews. Proc. zool. Soc. Lond., 123: 715-729.

6. Gębczyński M., 1965: Seasonal and age changes in the metabolism and activity of Sorex araneus Linnaeus, 1758. Acta theriol., 10: 303-331.

7. Janský L. \& Hanák V., 1960: Aktivität der Spitzmäuse unter natürlichen Bedingungen. Säugetierkdl. Mitt., 6: 55-63.

8. Loxton R. G., Raffaeli D. \& Begon M., 1975: Coprophagy and the diurnal cycle of the common shrew, Sorex araneus. J. Zool., Lond., 177: 449-453.

9. Mezhzherin V. A., 1960: Population density of the common shrew (Sorex araneus L.) and its changes over 17 years. Zool. Ż., 39: 1080-1087.

10. Newman J. R. \& Rudd R. L., 1978: Observations of torpor-like behaviour in the shrew, Sorex sinuosus. Acta theriol., 23: 436-438.

11. Pankakoski E., 1979: The influence of weather on the activity of the common shrew (Sorex araneus). Acta theriol., 24: 522-526.

12. Pernetta J. C., 1977: Population ecology of British shrews in grassland. Acta theriol., 22: 279-296.

13. Shillito J. F., 1963: Observations on the range and movements of a woodland population of the common shrew, Sorex araneus L. Proc. zool. Soc. Lond. 140: $533-546$.

14. Tupikova N. V., 1949: The diet and nature of the daily cycle of activity of shrews from the central region of U.S.S.R. Zool. Ż., 28: $561-572$.

15. Wolk E., 1969: Body weight and daily food intake in captive shrews. Acta theriol., $14: 35-47$.

Accepted, March 15, 1982.

\section{Sara CHURCHFIELD}

\section{WPŁYW TEMPERATURY NA AKTYWNOSC I KONSUMPCJE POKARMU U RYJOWKI}

\section{Streszczenie}

Badano aktywność Sorex araneus Linnaeus, 1758, fotografując co 15 sekund zwierzęta w klatce i rejestrując konsumpcję pokarmu w klatce metabolicznej latem i zimą w naturalnych warunkach oświetlenia i temperatury. Ryjówki są aktywne w ciągu całej doby latem, ze zwyżką aktywności nocą w porównaniu do dnia $\mathrm{i}$ to zarówno latem jak i zimą (Tabela 1). Aktywność była większa w lecie niż w zimie. Ryjówki są aktywne poza gniazdem latem przez $28 \%$ doby, a zima tylko przez $19 \%$ (Ryc. 1). Poszczególne okresy aktywności trwają 6 minut w lecie i 3 minuty w zimie. Okres spoczynku w gnieździe ma tendencję do wydlużania się $\mathrm{w}$ temperaturach zimowych $\left(\max .5^{1 / 4}\right.$ godz.) $\mathrm{w}$ porównaniu $\mathrm{z}$ temperaturami 